\title{
Investigation of the knowledge level, attitudes, and behaviors about sun protection and sunscreen in adolescent athletes
}

\author{
Adölesan sporcularda güneșten korunma ve güneș kremi ile ilgili bilgi düzeyi, tutum
}

ve davranıșların araștırılması

\section{Havva Hilal Ayvaz, ๑ Hüseyin Tolga Acar*, ๑ Sabriye Ercan*, ๑ Cem Çetin*}

Süleyman Demirel University Faculty of Medicine, Department of Dermatology and Venereology; *Department of Sports Medicine,

Isparta, Turkey

\begin{abstract}
Background and Design: This study aims to evaluate the knowledge level of adolescent licensed athletes between the ages of 12 and 18 years about sun protection and sunscreen use.

Materials and Methods: In our province, 644 adolescents engaged in sports under license were included in the study. Samples were selected by the stratification method. The questionnaires were filled by face-to-face interview techniques in the athletes' training environment. Demographic data of the participants were recorded. Then, the participants were administered the Sun Protection and Use of Sunscreen Change Stages scales and Sun Protection Behavior scale, Sun Protection Decision Balance scale, Sun Protection Self-Efficacy scale, which were prepared based on the transtheoretical model (TTM) theory. Adolescent athletes were divided into two groups according to the place where they train/match as "Indoor" (Group indoor) and "Outdoor" (Group outdor $_{\text {) }}$ ) athletes.

Results: While $59 \%(n=380)$ of the athletes participate in training/competition indoors (Group $\left.{ }_{\text {indoor }}\right), 41 \%(n=264)$ of the athletes participate in outdoors (Group ${ }_{\text {outdor }}$ ). According to TTM; $60.2 \%(n=388)$ of the athletes are at the stage of "precontemplation", and $12.7 \%(n=82)$ of the Sun Protection Change Stages are "maintenance". On the other hand, it was determined that $69.1 \%(n=445)$ of the athletes were in the step of "precontemplation", and 10.7\% ( $n=69)$ of the "maintenance" step of the use of sunscreen change stage scale. The scale results administered to adolescent athletes did not differ between the groups ( $p>0.05)$.

Conclusion: In light of the data we obtained from our study, it was determined that the adolescent age group athletes have a low level of knowledge about sun protection, sunscreen use, and skin cancer, regardless of sports discipline in the outdoors or indoors. We recommend training and counseling for all adolescent athletes about the harmful effects of the sun.
\end{abstract}

Keywords: Adolescent, skin neoplasms, transtheoretical model, sunscreens

\section{Öz}

Amaç: Bu çalışmada, 12-18 yaş arası adölesan lisanslı sporcuların güneşten korunma ve güneş koruyucu kullanımı ile ilgili bilgi düzeylerini değerlendirmek amaçlanmıştır.

Gereç ve Yöntem: ilimizde, lisanslı olarak spor yapan 644 adölesan çalışmaya dahil edilmiştir. Örneklem; tabakalama yöntemi ile seçilmiştir. Anketler sporcuların antrenman yaptıkları ortamda, yüz yüze görüşme tekniği ile doldurulmuştur. Katııımcıların; demografik verileri kaydedilmiştir. Ardından katılımcılara, transteoretik model (TTM) kuramı baz alınarak hazırlanan; Güneşten Korunma ve Güneş Koruyucu Kullanma Değişim Aşamaları ölçekleri ile Güneşten Korunma Davranış ölçeği, Güneşten Korunma Karar Dengesi ölçeği, Güneşten Korunma Öz Yeterlilik ölçeği uygulanmıştır.

Bulgular: Sporcuların \%59'u ( $n=380)$ iç mekanda $\left(G_{\text {rup }}\right.$ kapall $)$ \% $\% 1^{\prime} \mathrm{i}(\mathrm{n}=264)$ dış mekanda (Grup ack $)$ antrenmana/müsabakaya katılmaktadır. TTM'ye göre; sporcuların \%60,2'si (n=388) Güneşten Korunma Değişim Aşamalarının "düşünmęme", \%12,7'si (n=82) "sürdürme"

Address for Correspondence/Yazışma Adresi: Hawva Hilal Ayvaz MD, Süleyman Demirel University Faculty of Medicine, Department of Dermatology and Venereology, Isparta, Turkey Phone: +90 5309505907 E-mail: drhhilalayvaz@gmail.com

Received/Geliş Tarihi: 09.06.2020 Accepted/Kabul Tarihi: 19.11.2020 ORCID: orcid.org/0000-0002-6576-2431

Cite this article as: Ayvaz HH, Acar HT, Ercan S, Çetin C. Investigation of the knowledge level, attitudes, and behaviors about sun protection and sunscreen in adolescent athletes. Turkderm-Turk Arch Dermatol Venereol 2021;55:75-80.

(c) Copyright 2021 by Turkish Society of Dermatology and Venereology

Turkderm - Turkish Archives of Dermatology and Venereology published by Galenos Yayınevi. 
basamağındadır. Diğer taraftan; sporcuların \%69,1'inin ( $n=445)$ Güneş Koruyucu Kullanma Değişim Aşamalarının "düşünmeme", \%10,7'sinin (n=69) "sürdürme" basamağında olduğu tespit edilmiştir. Adölesan sporculara uygulanan ölçek sonuçlarında gruplar arasında fark belirlenmemiştir ( $p>0,05$ ).

Sonuç: Çalışmamızdan elde ettiğimiz veriler ışığında, açık ya da kapalı alanda spor yapmaktan bağımsız olarak, adölesan yaş grubundaki sporcuların güneşten korunma, güneş koruyucu kullanımı ve deri kanseri konusunda bilgi düzeylerinin düşük olduğu tespit edilmiştir. Öncelikle dış mekan sporcuları olmak üzere tüm adölesan sporculara, güneşin zararlı etkileri hakkında eğitim ve danışmanlık yapılmasını önermekteyiz.

Anahtar Kelimeler: Adölesan, deri neoplazmları, transteoretik model, güneş koruyucular

\section{Introduction}

Sun lights serve as an essential building block in many physiological functions of people. Regular exposure to sunlight positively affects human health, supported by experimental and clinical research ${ }^{1}$. Among the positive effects of the sun on human health, the best known are the prevention and treatment of some skin diseases (such as psoriasis and eczema), vitamin D synthesis (essential for bone and muscle health), and prevention and treatment of seasonal mood disorder ${ }^{2}$. In addition, recent studies revealed new and positive relationships between sunlight and some diseases. There is scientific evidence that regular exposure to sunlight can contribute to the prevention of colorectal, breast, and prostate cancers and non-Hodgkin's lymphoma ${ }^{3,4}$. Similarly, the protective and therapeutic effects of regular sun exposure against diseases, such as multiple sclerosis, hypertension, diabetes mellitus, and coronary artery disease, have been scientifically demonstrated ${ }^{5-8}$.

In addition to the positive effects of sun lights, there are also several negative effects, especially the development of skin cancer. Skin cancer is the most common cancer type in the world and is one of the five cancer types with the highest cost regarding health expenditures ${ }^{9}$. Recreational sunbathing and sunbathing activities started gaining popularity in the early twentieth century'. However, in the following years, an increase in the incidence of skin cancer was recorded in northern Australia, which has a subtropical climate and a population with a highly sun-sensitive skin type ${ }^{10}$. Many studies examined the relationship between skin cancer and sun lights. The results of these studies led the World Health Organization to conclude in 1992 that solar ultraviolet (UV) rays are the leading environmental cause of skin cancer ${ }^{11}$. The cumulative effects of genetic predisposition and environmental exposure (primarily due to UVB) are responsible for the development of skin cancer ${ }^{2}$. Sancar ${ }^{12}$ stated that the nucleotide excision repair system, which is among the cell repair mechanisms, eliminates genotoxic effects (formation of pyrimidine dimers) caused by UVB rays on genes ${ }^{12}$.

At present, the incidence of skin cancer has increased approximately three times due to the widespread exposure to sun lights, especially for tanning purposes ${ }^{13}$. In addition to sunbaths, beach activities, and outdoor sports are activities preferred mainly by adolescents. In the early afternoon hours when UV radiation is at its peak, adolescents, in particular, are at high risk for developing sunburn if sun protection (such as suitable clothing, hats, sunglasses) is inadequate and/or sunscreen is used incorrectly or insufficiently ${ }^{14}$. This type of sunburn that develops during adolescence will be an essential precursor lesion for the development of skin cancer in the future. Studies indicate that sunburn is common (>70\%) among young people. Also, their perception of the risk of developing skin cancer is low and their widespread belief that tanned skin is attractive ${ }^{15}$. On the other hand, behavior change can be achieved in many areas with the transtheoretical model (TTM) developed by Prochaska and Velicer ${ }^{16}$ and DiClemente ${ }^{17}$. Behavior change in this model consists of five stages: "Precontemplation, contemplation, preparation, action, and maintenance"16,18. In studies conducted in both adults and adolescents, the application of this model was effective in determining the change in behavior about sun protection and sunscreen use ${ }^{19-21}$. This study evaluates the level of knowledge, attitudes, and behaviors of adolescent athletes about sun protection and sunscreen use based on the TTM theory.

\section{Materials and Methods}

When the sample size was determined according to the number of active adolescent athletes in our province (confidence level: 99\%, precision rate: 0.05 ), it was determined that at least 613 athletes should be reached. The sample was selected by stratification according to gender, age, and sports discipline. The questionnaires were completed using the face-to-face interview technique in the athletes' training environment. The study was approved by the Local Ethics Committee of Süleyman Demirel University Faculty of Medicine (approval number: 33, date: 13.02.2020). Informed consent was obtained from adolescent athletes and their parents.

The demographic data of the participants were recorded. Then, the participants completed the Sun Protection and Sunscreen Use Change Stages scales and Sun Protection Behavior scale, Sun Protection Decision Balance scale, and Sun Protection Self-Efficacy scale, which were prepared based on TTM theory. Adolescent athletes were divided into two groups according to the place where they train/match as "indoor" (Group indoor $_{\text {) }}$ ) and "outdoor" (Group outdoor $)$ athletes.

\section{Introductory information form}

It consists of descriptive information, such as age, height, body weight, gender, sports branch, how many years the athletes are licensed athletes, weekly training time (hours), the place where they train (indoors/outdoors), economic status of their families, hair-eye-skin color, and skin type.

\section{Transtheoretical model-Sun Protection Stage of Change scale and Use of Sunscreen Stage of Change scales}

The Sun Protection Change Stages scale consists of four questions to measure the continuity in basic behaviors to avoid continuous sun exposure, such as using a sunscreen with at least 15 factors, using sunscreen clothing and hats, and not going out in the sun between $10.00 \mathrm{am}$ and $4.00 \mathrm{pm}$. The possible answers of the participants to these questions are "yes" or "no." Based on the answers given, the participant's TTM change stages are determined ${ }^{19}$

The Sun Protection Change Levels scale consists of four questions used to measure the continuity in sun protection intentions and behaviors using a sunscreen with at least 15 factors, similar to the Sun Protection Change Levels scale. The answers "yes" and "no" to the questions indicate the behavior change stage of the participant according to the $T_{T} \mathrm{M}^{19}$.

Validity and reliability studies of the Turkish forms of the Sun Protection and Sunscreen Use Change Stages scales have been conducted ${ }^{22}$. 


\section{Sun Protection Behavior scale}

The Turkish version of the Sun Protection Behavior scale is a five-point Likert-type scale consisting of eight items. It is used to measure the frequency of sun protection behavior when exposed to the sun for more than fifteen minutes. The scale has three sub-dimensions, such as regular sun exposure avoidance (3-15 points), using sunscreen (3-15 points), and using a hat (2-10 points) ${ }^{23}$. The lowest score that can be obtained from the scale is 8 , and the highest score is $40^{23}$.

\section{Sun Protection Decisional Balance scale}

The Sun Protection Decisional Balance scale is a 5-point Likert-type scale that determines the importance of the decisions that the participants can make for sun protection. It consists of two subscales measuring the perception of sun exposure for benefit ( 4 items) and harm (4 items). According to this scale, items $1,3,5$, and 7 constitute the perception of benefit, whereas items $2,4,6$, and 8 constitute the perception of harm ${ }^{24}$.

As a result of the responses given to the items in the scale, besides the total score, the scores of the benefit and loss subscales are calculated separately. While the lowest scores of benefit and loss perceptions subscales are 4, the highest scores are 20 . Validity and reliability studies of the Turkish forms of the scale have been conducted ${ }^{25}$.

\section{Transtheoretical model-Sun Protection Self-Efficacy Confidence}

It is a five-Likert-type scale consisting of three subscales and nine items in total: Sun avoidance (3-15 points), sunscreen use (3-15 points), and hat use (2-10 points). The lowest score obtained from the scale is 9 , and the highest score is $45^{24}$. Validity and reliability studies of the Turkish forms of the scale have been conducted ${ }^{25}$.

\section{Statistical Analysis}

SPSS v.23 package program was used to analyze the data. After performing descriptive statistical methods and determining the suitability for normal distribution with the Skewness-Kurtosis test, the t-test was used for numerical data. The chi-square test was used for non-numerical data. Data are presented as percent and mean \pm standard deviation. A p-value was accepted as significant at the 0.05 level.

\section{Results}

The study participants consisted of 644 adolescent athletes (female: $42.9 \%$, male: $57.1 \%$ ) with an average age of $14.6 \pm 0.8$ years. The average duration of participating in licensed sports was $3.1 \pm 0.8$ years, and weekly training time was $5.7 \pm 0.2$ hours. Also, $59 \%(n=380)$ of the athletes participated in training/competition indoors (Group indoor $_{\text {) }}$ ) and $41 \%(n=264)$ outdoors (Group outdoor $_{\text {) }}$.

The participants were asked to define their family income levels into five groups and their distribution was as follows; $0.2 \%(n=1)$ very low, $1.2 \%(n=8)$ low, 49.8\% ( $n=321) \mathrm{mid}, 43.3 \%(\mathrm{n}=279)$ good, and $5.4 \%$ $(n=35)$ very good.

The most common hair colors of athletes were brown (35.6\%, $\mathrm{n}=229)$ and black (31.5\%, $n=203)$. Brown (66.9\%, $n=431)$ and hazel $(13.2 \%$, $\mathrm{n}=85$ ) were the most common eye colors. When the participants were asked to describe their skin type, they preferred the words "It burns very little, it tans easily $(23.8 \%, \mathrm{n}=153)$, " then "It burns, but tans over time $(22.7 \%, \mathrm{n}=146)^{\prime \prime}$.
When questioned about their history of sunburn in the last 12 months, $50 \%(n=322)$ of the athletes said "I did not have", 26.7\% ( $n=172)$ once, $16.8 \%(n=108)$ two times, and $6.5 \%(n=42)$ three or more. When asked about the number of sunburns before the age of twelve, $23.4 \%(n=151)$ of all participants had three or more, $19.7 \%(n=127)$ had two times, and $19.3 \%(n=124)$ had a sunburn one time. The history of skin disease in the family history was in $6.1 \%(n=39)$ of the athletes, whereas skin cancer history was in $0.6 \%(n=4)$ of the athletes. When the athletes are divided into two groups as open field (Group outdoor) and closed field (Group indoor $_{\text {) }}$ ) athletes according to the field they train, the difference is determined concerning gender. It was determined that female athletes frequently prefer indoors (212 women, 55.8\%; 168 men, 44.2\%), and male athletes often prefer outdoors (200 men, $75.8 \%$; 64 women, 24.2\%) ( $p=0.0001)$. According to the weekly training time $\left(p=0.0001\right.$; Group $_{\text {outdoor }}: 6.8 \pm 0.3$ hours, Group indoor $: 5 \pm 0.2$ hours), hair color ( $p=0.006$; brown hair color Group indoor 65.1\%, Group $_{\text {outdoor: }}$ 34.9\%; black hair color Group indoor : 51.2\%, Group outdoor $48.8 \%$ ), skin color ( $p=0.0001$; brown-light brown skin color Group $p_{\text {indoor }}$ $66.2 \%$, Group outdoor $_{33.8 \% \text {; brown skin color Group }}$ indoor $45.7 \%$, Group $\left._{\text {outdoor }}: 54.3 \%\right)$, there were differences between the groups.

According to age $(p=0.3)$, licensed athlete time $(p=0.8)$, economic status ( $p=0.05)$, eye color $(p=0.4)$, skin type $(p=0.07)$, sunburn history in the last 12 months $(p=0.9)$, history of sunburn before the age of 12 $(p=0.4)$, history of skin disease $(p=0.2)$ and/or skin cancer $(p=0.3)$ in the family, Sun Protection Change Stages $(p=0.5)$, and Use of Sunscreen Change Stages $(p=0.3)$ data, there was no difference between the groups.

There was no difference between the groups according to the results of the "Sun Protection Behavior scale," "Sun Protection Decision Balance scale," and "Sun Protection Self-Efficacy scale" administered to adolescent athletes ( $p>0.05$ ) (Table 1). The distribution of athletes according to the Sun Protection Change Stages scale and the use of the Sunscreen Stage of Change Scale are shown in Table 2.

\section{Discussion}

Some restrictions may be faced regarding the precautions to be taken to be protected from the unwanted effects of the sun, especially during physical activities or sports training/competitions performed outdoors and under aerobic conditions.

Competition or race rules can be a formidable obstacle in sun protection in many sports branches ${ }^{26}$. At the same time, sports clothes or clothes that will be worn during physical activity may not have good ergonomics to protect all body parts from the sun ${ }^{27,28}$. The rules on using such clothing and equipment make sun protection behaviors and attitudes even more important for athletes in related disciplines. In light of all this information, sunscreen is considered the most basic form of sunscreen behavior that should be given priority and should be used by every individual since puberty ${ }^{28}$.

A chronic, intermittent and cumulative UV radiation exposure has been accepted as the main risk factor in the development of skin cancer ${ }^{29}$. In addition, the number of harmful sun lights exposed and sunburns until the age of 21 may play an essential role in the pathogenesis of various skin cancer types ${ }^{30}$. Studies have reported that individuals in the adolescent age group and following in the youth are prone to show risky behaviors regarding sun exposure ${ }^{30,31}$. In the questionnaire we used in 
Table 1. Evaluation of scales by groups

\begin{tabular}{|l|l|l|l|}
\hline & $\begin{array}{l}\text { Group }_{\text {indoor }} \\
(\mathbf{n = 3 8 0 )}\end{array}$ & $\begin{array}{l}\text { Group }_{\text {outdoor }} \\
(\mathbf{n = 2 6 4 )}\end{array}$ & p-value \\
\hline SPBS-Avoiding the sun & $8.6 \pm 0.1$ & $8.1 \pm 0.2$ & 0.05 \\
\hline SPBS-Use of sunscreen & $6.5 \pm 0.2$ & $6 \pm 0.2$ & 0.06 \\
\hline SPBS-Use of a hat & $5.1 \pm 0.1$ & $5.2 \pm 0.1$ & 0.4 \\
\hline SPBS (total score) & $20.1 \pm 0.3$ & $19.4 \pm 0.4$ & 0.1 \\
\hline SPDBS-Perceived benefit & $11.1 \pm 0.2$ & $10.8 \pm 0.3$ & 0.3 \\
\hline SPDBS-Lack of protection & $8.8 \pm 0.2$ & $9 \pm 0.2$ & 0.5 \\
\hline SPDBS (total score) & $19.9 \pm 0.3$ & $19.8 \pm 0.4$ & 0.8 \\
\hline SPSEC-Avoiding the sun & $7.7 \pm 0.2$ & $7.8 \pm 0.2$ & 0.6 \\
\hline SPSEC-Use of sunscreen & $10.6 \pm 0.2$ & $10.1 \pm 0.3$ & 0.2 \\
\hline SPSEC-Use of a hat & $5.3 \pm 0.1$ & $5.6 \pm 0.2$ & 0.2 \\
\hline SPSEC (total score) & $23.6 \pm 0.4$ & $23.5 \pm 0.5$ & 0.9 \\
\hline SPBS: Sun Protection Behavis & scal SPDBS: Sun Protecton
\end{tabular}

SPBS: Sun Protection Behavior scale, SPDBS: Sun Protection Decisional Balance scale, SPSEC: Sun Protection Self-Efficacy Confidence, a p-value was accepted as significant at the 0.05 level

Table 2. Distribution of athletes according to the Sun Protection Change Stages scale and the use of the Sunscreen Stage of Change scale

\begin{tabular}{|l|l|l|}
\hline & $\begin{array}{l}\text { The Sun Protection } \\
\text { Change Stages } \\
\text { scale } \mathbf{( n , \% )}\end{array}$ & $\begin{array}{l}\text { The use of } \\
\text { Sunscreen Stage } \\
\text { of Change scale } \\
\mathbf{( n , \% )}\end{array}$ \\
\hline Precontemplation stage & $388(60.3 \%)$ & $445(69.1 \%)$ \\
\hline Contemplation stage & $53(8.2 \%)$ & $52(8.1 \%)$ \\
\hline Preparation stage & $41(6.4 \%)$ & $40(6.2 \%)$ \\
\hline Action stage & $80(12.4 \%)$ & $38(5.9 \%)$ \\
\hline Maintenance stage & $82(12.7 \%)$ & $69(10.7 \%)$ \\
\hline Total & $644(100 \%)$ & $644(100 \%)$ \\
\hline
\end{tabular}

our study, the question of "How many times have you had sunburn in the last year?" was answered by $26.7 \%(n=172)$ of the athletes as one time, $16.8 \%$ of $(n=108)$ as two times, and $6.5 \%(n=42)$ of as three or more times. Similar to our results, in a study from our country based on a similar age group sample, $22.4 \%$ of the participants answered the same question as experiencing sunburn once, $17.6 \%$ of as twice, and $16.3 \%$ of as three or more times ${ }^{22}$. In addition, in a study from New Zealand, the sun protection behavior of 1225 child athletes between the ages of 13 and 18 and 215 heads of the school or competition officials were examined during the competitions at noon. Results revealed that only $3.4 \%$ of the athletes use a protective hat, whereas $25.4 \%$ of the officials use a protective hat. The percentage of clothing that protects the extremities under the elbow and knee from the sun was similarly lower in the adolescent group than the authorities ${ }^{31}$. Due to children in the adolescent age group and adults in the young age group are more likely to participate in active sports in outdoor and organized sports than in other age groups, they are accepted as high priority group in terms of protection from sun exposure and skin cancer prevention $^{32}$.
In light of all this information, informing, educating, and consulting adolescent athletes, their families, and coaches about sun protection methods is vital in preventing various dermatological disorders, especially skin cancers, which may be encountered in the future.

In the summertime and at noon, the sun lights may have more harmful effects on adolescent athletes while training outdoors. Also, some specific physiological conditions may exacerbate these harmful effects. For example, with sweating, the minimal erythema dose (MED), a measure that determines the minimum amount of UV radiation that can cause a sunburn or erythema, is significantly reduced. The presence of sweat increases the hydration of the stratum corneum layer, the outermost layer of the skin, decreases the reflection of UV rays and increases the harmful effects of UV ${ }^{33}$. After only a 15-minute jog or run, a $40.9 \%$ reduction in MED is observed ${ }^{33}$. In addition, in a study evaluating the personal UV exposure of professional cyclists, each athlete's MED decreased by an average of eight times compared with their pre-competition stage ${ }^{34}$. Based on this information, the application of sun protection methods should be encouraged for individuals who will have any physical activity in the summertime, alfresco, and/or a prolonged duration activity.

Two different studies that used the same scales in our study found that the rates of participants in the TTM exchange stages were similar to our findings. One of these studies evaluated 180 participants of similar age groups, and the other had 1200 adolescent participants in Sweden ${ }^{22,35}$. Although the adolescent age group is in different societies, this similarity in behavioral attitudes may be attributed to the popularity and inadequate education of sunbathing and tanning behaviors in individuals at this age.

According to the results of our study, female adolescent athletes more frequently preferred indoor sports, whereas male adolescent athletes preferred outdoor sports $(p=0.0001)$. In the literature, similar to our results, female adolescent athletes had less physical activity and participation rates in outdoor sports training or competition than male adolescent athletes ${ }^{36}$. Although prolonged exposure to the sun is at high risk for the harmful effects of health, professional outdoor athletes and recreational athletes exercising outdoors often do not comply with adequate sun protection behaviors and practices. In a study on 290 NCAA collegiate athletes who train outdoors for an average of four hours a day, less than $10 \%$ of respondents reported using regular sunscreen ${ }^{37}$. Similarly, in another study with 554 adolescent athletes in Argentina, only $5 \%$ of athletes stated that they regularly use sunscreen ${ }^{38}$. Findings in the literature and the results of our study suggest that individuals in adolescence who are competing/training outdoors can have a high risk of encountering various skin cancers in adulthood because of exposure to the sun's harmful rays. Several sun protection methods and behaviors are recommended for all athletes, especially adolescent athletes (Table 2 ) $^{39}$.

More important than the degree of a protective factor in its content in providing optimal protection from the sun is the application of sunscreen. Thus, the sunscreen cream-lotion application should be applied as $2 \mathrm{mg} / \mathrm{cm}^{2}$, and if it is to be spent outdoors for a long time, the application should be repeated every two hours ${ }^{40}$.

\section{Study Limitations}

Since our study sample consists of licensed athletes in our city and our country has regions with a wide range of climatic and geographical 
features. It may be a limitation that the results obtained cannot be generalized to all adolescent athletes in our country. In addition, the frequency and amount of use not mentioned during the use of sunscreen can be stated as the second limitation of our study.

\section{Conclusion}

Adolescent athletes participating in outdoor sports are at risk for skin cancer in their future lives due to exposure to UV rays during training or during sports competitions. In addition to this current risk, many adolescent athletes do not have sufficient knowledge about harmful UV rays and do not use sunscreen cream-lotion or sunscreen to protect their skin. When skin cancer is encountered, the costs that can be spent during the diagnosis, treatment, and rehabilitation can find relatively high amounts. We suggest that providing education and counseling to individuals in the adolescent age group with high sun exposure, especially outdoor athletes, and all children, and related adults such as parents, school principals, coaches, would be a more practical approach both in terms of cost and to protect public health.

Acknowledgments: We would like to thank all the trainers and physical education and sports teachers in our province, especially retired teacher Mr. Ayhan Acar, who helped us a lot during the data collection process.

\section{Ethics}

Ethics Committee Approval: The study was approved by the Local Ethics Committee of Süleyman Demirel University Faculty of Medicine (approval number: 33, date: 13.02.2020).

Informed Consent: Informed consent was obtained from adolescent athletes and their parents.

Peer-review: Externally peer-reviewed.

\section{Authorship Contributions}

Concept: H.H.A., H.T.A., S.E., C.Ç., Design: H.H.A., H.T.A., S.E., C.Ç., Data Collection or Processing: H.H.A., H.T.A., S.E., C.Ç., Analysis or Interpretation: H.H.A., H.T.A., S.E., C.Ç., Literature Search: H.H.A., H.T.A., S.E., C.Ç., Writing: H.H.A., H.T.A., S.E., C.Ç.

Conflict of Interest: No conflict of interest was declared by the authors.

Financial Disclosure: The authors declared that this study received no financial support

\section{References}

1. van der Rhee H, de Vries E, Coebergh JW: Regular sun exposure benefits health. Med Hypotheses 2016;97:34-7.

2. Lucas $R$, Norval $M$, Neale $R$, et al: The consequences for human health of stratospheric ozone depletion in association with other environmental factors. Photochem Photobiol Sci 2015;14:53-87.

3. van Der Rhee H, Coebergh JW, De Vries E: Is prevention of cancer by sun exposure more than just the effect of vitamin $D$ ? A systematic review of epidemiological studies. Eur J Cancer 2013;49:1422-36.

4. Rebel H, der Spek CDv, Salvatori D, van Leeuwen JP, Robanus-Maandag EC, de Gruijl FR: $V$ exposure inhibits intestinal tumor growth and progression to malignancy in intestine-specific Apc mutant mice kept on low vitamin D diet. Int J Cancer 2015;136:271-7.

5. Wong A: Incident solar radiation and coronary heart disease mortality rates in Europe. Eur J Epidemiol 2008;23:609-14.
6. Modesti PA, Morabito M, Massetti L, et al: Seasonal blood pressure changes: an independent relationship with temperature and daylight hours. Hypertension 2013;61:908-14.

7. Mohr SB, Garland CF, Gorham E, Garland FC: The association between ultraviolet $B$ irradiance, vitamin $D$ status and incidence rates of type 1 diabetes in 51 regions worldwide. Diabetologia 2008;51:1391-8.

8. Shore-Lorenti C, Brennan SL, Sanders KM, Neale RE, Lucas RM, Ebeling PR: Shining the light on Sunshine: a systematic review of the influence of sun exposure on type 2 diabetes mellitus-related outcomes. Clin Endocrinol (Oxf) 2014;81:799-811.

9. Housman TS, Feldman SR, Williford PM, et al: Skin cancer is among the most costly of all cancers to treat for the Medicare population. J Am Acad Dermatol 2003;48:425-9.

10. Albert MR, Ostheimer KG: The evolution of current medical and popular attitudes toward ultraviolet light exposure: part 2. J Am Acad Dermatol 2003;48:909-18.

11. Solar I: Ultraviolet radiation. Lyon, France: IARC Monographs on the Evaluation of Carcinogenic Risks to Humans, International Agency for Research on Cancer. World Health Organization 1992.

12. Sancar A: Mechanisms of DNA excision repair. Science 1994;266:1954

13. Molho-Pessach $V$, Lotem $M$ : Ultraviolet radiation and cutaneous carcinogenesis. Curr Probl Dermatol 2007;35:14-27.

14. Berndt NC, O'Riordan DL, Winkler E, McDermott L, Spathonis K, Owen N: Social cognitive correlates of young adult sport competitors' sunscreen use. Health Educ Behav 2011;38:6-14

15. Fernández-Morano T, de Troya-Martín M, Rivas-Ruiz F, et al: Sun exposure habits and sun protection practices of skaters. J Cancer Educ 2017;32:734-9.

16. Prochaska JO, Velicer WF: The transtheoretical model of health behavior change. Am J Health Promot 1997;12:38-48.

17. Erol S, Erdoğan S: Application of transtheoretic model for improving and changing health behaviours Sağlık davranışlarını geliştirmek ve değiştirmek için transteoretik modelin kullanılması. Anadolu Hemşirelik ve Sağlık Bilimleri Dergisi 2007;10:86-94.

18. Velicer WF, Prochaska JO, Fava JL, Norman GJ, Redding CA: Smoking cessation and stress management: applications of the transtheoretical model of Behavior change. Homeostasis 1998;38:216-33.

19. Rossi JS, Blais LM, Redding CA, Weinstock MA: Preventing skin cancer through behavior change. Implications for interventions. Dermatol Clin 1995; 13:613-22.

20. Weinstock MA, Rossi JS, Redding CA, Maddock JE: Randomized controlled community trial of the efficacy of a multicomponent stage-matched intervention to increase sun protection among beachgoers. Prev Med 2002;35:584-92.

21. Adams MA, Norman GJ, Hovell MF, Sallis JF, Patrick K: Reconceptualizing decisional balance in an adolescent sun protection intervention: mediating effects and theoretical interpretations. Health Psychol 2009;28:217-25.

22. Aygün $O$, Ergun $A$ : The impact of sun protection program on the sun protection behavior of adolescents. Clin Exp Health Sci 2018;8:166-74.

23. Aygun $\mathrm{O}$, Ergun A: Validity and reliability of sun protection behavior scale among Turkish adolescent population. Asian Nurs Res 2015;9:235-42.

24. Maddock JE, Redding CA, Rossi JS, Weinstock MA: Development and validation of an appearance motivation attitudes scale for sun protection. Psychology \& Health 2005;20:775-88.

25. Aygun O, Ergun A: Decisional balance and self-efficacy for sun protection: measurement among Turkish adolescents. Nurs Res 2014;63:309-19.

26. Wolf ST, Kenney LE, Kenney WL: Ultraviolet radiation exposure, risk, and protection in military and outdoor athletes. Curr Sports Med Rep 2020;19:137-41.

27. Lawler S, Spathonis K, Eakin E, Gallois C, Leslie E, Owen N: Sun exposure and sun protection behaviours among young adult sport competitors. Aust N Z J Public Health 2007;31:230-4.

28. Lawler S, McDermott L, O'Riordan D, et al: Relationships of sun-protection habit strength with sunscreen use during outdoor sport and physical activity. Int J Environ Res Public Health 2012;9:916-23. 
29. Holick MF: Biological effects of sunlight, ultraviolet radiation, visible light, Infrared radiation and vitamin d for health. Anticancer Res 2016;36:134556.

30. De Castro-Maqueda G, Gutierrez-Manzanedo J, Ponce-González J, FernandezSantos JR, Linares-Barrios M, De Troya-Martín M: Protection habits and sunburn in elite aquatics athletes: surfers, windsurfers and olympic sailors. J Cancer Educ 2020;35:312-20.

31. McNoe BM, Reeder Al: Adolescent sun protection at secondary school athletic sporting events - a misnomer. Aust N Z J Public Health 2016;40:3135 .

32. Leslie E, Cerin E, Gore CJ, George AS, Bauman A, Owen N: Gender, age, and educational-attainment differences in Australian adults' participation in vigorous sporting and fitness activities. J Phys Act Health 2004;1:377-88.

33. Hamant ES, Adams BB: Sunscreen use among collegiate athletes. J Am Acad Dermatol 2005;53:237-41.

34. Moehrle M, Heinrich L, Schmid A, Garbe C: Extreme UV exposure of professional cyclists. Dermatology 2000;201:44-5.
35. Kristjánsson S, Bränström $\mathrm{R}$, Ullén $\mathrm{H}$, Helgason AR: Transtheoretical model: investigation of adolescents' sunbathing behaviour. Eur J Cancer Prev 2003;12:501-8

36. Vilhjalmsson R, Kristjansdottir G: Gender differences in physical activity in older children and adolescents: the central role of organized sport. Soc Sci Med 2003;56:363-74

37. Wysong A, Gladstone H, Kim D, Lingala B, Copeland J, Tang JY: Sunscreen use in NCAA collegiate athletes: identifying targets for intervention and barriers to use. Prev Med 2012;55:493-6.

38. Laffargue JA, Merediz J, Buján MM, Pierini AM: Sun protection questionnaire in Buenos Aires adolescent athletes. Arch Argent Pediatr 2011;109:30-5.

39. Jinna S, Adams BB: Ultraviolet radiation and the athlete: Risk, sun safety, and barriers to implementation of protective strategies. Sports Med 2013:43:531-7

40. Food and Drug Administration: Sunscreen drug products for over-the counter human use; proposed amendment of final monograph; proposed rule. Fed Regist 2007;72:49070-122. 